\title{
HUBUNGAN WAKTU PEMOTONGAN DAN WAKTU PEMESINAN PADA UJI KOMPTENSI PRAKTIK KEJURUAN TEKNIK PEMESINAN
}

\author{
Naufal Rizqan Ramadhan ${ }^{1}$, Wardaya ${ }^{2}$, Purnawan ${ }^{3}$ \\ Departemen Pendidikan Teknik Mesin \\ Universitas Pendidikan Indonesia \\ Jl. Dr. Setiabudhi No. 207 Bandung 40154 \\ naufalrizqanr@gmail.com
}

\begin{abstract}
ABSTRAK
Tujuan penelitian ini adalah untuk mengetahui hubungan antara waktu pemotongan dan waktu pemesinan pada pelaksanaan uji kompetensi praktik kejuruan dan untuk mengetahui distribusi penilaian aspek waktu pemesinan pada pelaksanaan uji kompetensi praktik kejuruan bidang pemesinan bubut. Penelitian dilakukan di SMK Taruna Mandiri Cimahi pada tahun ajaran 2013/2014. Metode yang digunakan dalam penelitian ini adalah metode deskriptif korelasional dengan subjek penelitian 1 kelas sebanyak 30 siswa. Data diperoleh melalui observasi langsung terhadap pelaksanaan uji kompetensi praktek kejuruan pemesinan bubut, pekerjaan bubut terdiri atas tujuh pekerjaan, yaitu: bubut rata, bubut muka, bubut alur, bubut tirus, bubut tepi, bubut kartel, dan boring. Hasil penelitian menunjukan bahwa terdapat hubungan yang positif antara waktu pemotongan dan waktu pemesinan pada pelaksanaan uji komptensi praktik kejuruan teknik pemesinan dengan tingkat hubungan yang sangat kuat. Distribusi penilaian untuk aspek waktu pemesinan bubut berturut-turut adalah $13 \%, 44 \%, 23 \%$, dan $20 \%$ masing-masing untuk kategori a, b, c, dan e.
\end{abstract}

Kata kunci: kejuruan, pemotongan, pemesinan, kompetensi, bubut

\begin{abstract}
The purpose from this research to know the relationship between the 2 objects before (severing time with machinery frais time) on implementation the practice competency test, vocational frais machining in Vocational High School 2 Bandung (SMKN 2 Bandung) Academic year 2013/2014. The method used in this research is descriptive correlational method, with 2 subjects research 2 class as much as 75 students. Data is obtained by way of the direct observation toward implementation the practice competency test vocational frais machining, the frais work is surrounded 3 process, there are flat frais, surface frais, and sloping frais regarding 7 sector. The result of this research it's point out that available positive relation between severing time with frais machinery time for practice competency test frais machinery in Vocational High School 2 Bandung with the strong level of the relation. Distribution to the aspect of assessment time pemesinan lathe is 13 consecutive $\% 44 \% 23 \%$, and $20 \%$ each for category a, b c and e.
\end{abstract}

Keyword: vocational, cutting, machining, competency, lathe

\footnotetext{
${ }^{1}$ Mahasiswa Departemen Pendidikan Teknik Mesin FPTK UPI

${ }^{2}$ Dosen Departemen Pendidikan Teknik Mesin FPTK UPI

${ }^{3}$ Dosen Departemen Pendidikan Teknik Mesin FPTK UPI
} 


\section{PENDAHULUAN}

Pelaksanaan uji kompetensi merupakan salah satu standar kelulusan siswa di SMK. Tujuan uji kompetensi adalah sebagai indikator ketercapaian standar kompetensi lulusan. Dalam pelaksanaannya standar penilaian pelaksanaan uji kompetensi telah ditentukan oleh Badan Standar Nasional Pendidikan. Kriteria yang dinilai pada pelaksanaan uji kompetensi praktik kejuruan meliputi aspek persiapan kerja, proses (sistematika dan cara kerja), hasil kerja, sikap kerja dan waktu (BSNP, 2013). Kelima aspek tersebut menjadi standar acuan penilaian pada proses ujian kompetensi praktik kejuruan. Berdasarkan aspek penilaian tersebut, kriteria penilaian waktu penyelesaian uji kompetensi praktik kejuruan, dalam format penilaian tersebut tidak terdapat indikator waktu standar pelaksaan kegiatan praktik yang dinilai dari awal persiapan sampai selesai. Indikator pencapaian yang tercantum dalam lembar penilaian (Tabel 1).

Tabel 1. Kriteria penilaian waktu ujian praktek kejuruan

\begin{tabular}{llc}
\hline \multicolumn{1}{c}{ Waktu } & \multicolumn{1}{c}{ Kriteria } & Skor \\
\hline Waktu penyelesaian & $\begin{array}{l}\text { Selesai tepat waktu dengan hasil baik dan } \\
\text { benar }\end{array}$ & $\begin{array}{l}\text { Selesai tepat waktu dengan hasil kurang baik } \\
\text { namun benar }\end{array}$ \\
\hline $\begin{array}{ll}\text { Selesai tidak tepat waktu dengan hasil baik } \\
\text { dan benar }\end{array}$ & 2 \\
\hline $\begin{array}{l}\text { Selesai tidak tepat waktu dengan kurang baik } \\
\text { dan salah }\end{array}$ & 1 \\
\hline & Tidak selesai & 0 \\
\hline
\end{tabular}

Permasalahannya adalah tidak adanya standar waktu kerja pada format penilaian di atas. Sesuai dengan pengalaman penulis ketika melakukan observasi langsung ke lapangan, siswa yang mengikuti uji kompetensi praktik kejuruan kurang merespon pekerjaan yang mereka kerjakan. Selain daripada itu, tidak adanya standar waktu yang jelas pada format penilaian menyulitkan assesor dalam menentukan penilaiannya, sehingga memungkinkan akan terjadinya kesalahpahaman dalam pemberian nilai. Format penilaian waktu yang dikeluarkan oleh BSNP kurang memberikan informasi yang jelas. Sehingga menimbulkan ketidakjelasan dalam menginformasikan waktu penyelesaian yang sebenarnya terjadi di lapangan. Padahal berdasarkan pedoman mengenai pelaksanaan uji kompetensi. Hasil dari uji kompetensi akan dijadikan informasi atas kompetensi yang dimiliki oleh para calon pekerja dalam hal ini adalah para peserta uji kompetensi.

Diperlukan format penilaian baru yang di dalamnya terdapat standar waktu penyelesaian yang jelas dan terukur. Sehingga dengan dibuatnya format penilaian baru 
tersebut dapat memecahkan permasalahan-permasalahan yang telah dipaparkan. Adapun cara yang dilakukan dalam menentukan standar waktu penyelesaian pada proses pelaksanaan uji kompetensi praktik kejuruan. Dibutuhkannya sebuah analisa mengenai waktu pengerjaan yang dilakukan siswa dalam melakukan pekerjaannya (Direktorat Pembinan SMK, 2013). Analisa waktu tersebut akan menentukan berapa waktu yang dibutuhkan untuk menyelesaikan suatu pekerjaan. Beberapa komponen waktu yang terdapat pada waktu pengerjaan bidang pemesinan bubut yakni, waktu pemotongan dan waktu pemesinan. Adanya analisa waktu tersebut dapat menentukan standar waktu yang nantinya dapat digunakan sebagai pedoman, baik bagi para siswa maupun bagi para assesor dalam menilai.

Penelitian ini bertujuan untuk mengetahui gambaran waktu pemotongan dan pemesinan yang dilakukan siswa dalam pelaksanaan uji kompetensi. Mengetahui hubungan antara waktu pemotongan dengan waktu permesinan bubut pada uji kompetensi, dan menghasilkan format penilaian waktu kerja pelaksanaan uji kompetensi pemesinan.

\section{METODE PENELITIAN}

Penelitian ini menggunakan metode deskriptif korelasional. Metode deskriftif korelasional merupakan penelitian yang dirancang untuk menentukan tingkat hubungan variabel-variabel yang berbeda dalam suatu populasi. Pada penelitian ini terdapat dua variabel, yaitu: waktu pemotongan uji kompetensi praktik kejuruan dan waktu pemesinan uji kompetensi praktik kejuruan. Penelitian yang dilakukan oleh penulis dilaksanakan di SMK Taruna Mandiri Cimahi, pada kompetensi bidang pemesinan. Penelitian dilakukan pada siswa kelas XII tahun pelajaran 2013/2014 yang terdiri atas satu kelas dengan jumlah siswa sebanyak 30 orang.

\section{HASIL PENELITIAN}

Setelah diperoleh data mengenai waktu pemotongan dengan waktu pemesinan hasil uji kompetensi praktik kejuruan bidang pemesinan. Hasil analisis terhadap data-data tersebut, dapat dilihat pada Tabel 2. Data yang telah diperoleh digunakan untuk mengestimasi nilai dari suatu variabel berdasarkan nilai variabel lainnya. Berdasarkan hasil analisis terhadap waktu hasil uji kompetensi praktek kejuruan, diperoleh persamaan umum regresi, yaitu: $\hat{Y}=73,64+2,07 \mathrm{X}$. Diketahui bahwa harga koefisien arah regresi linier $\mathrm{b}=$ 2,07 bertanda positif, sehingga dapat dinyatakan bahwa setiap kenaikan satu tingkat waktu 
pemotongan diprediksi akan berakibat meningkatnya nilai waktu pemesinan sebesar 2,07 pada setiap tingkatnya.

Tabel 2. Data waktu pemotongan dan pemesinan

\begin{tabular}{|c|c|c|c|}
\hline \multicolumn{2}{|l|}{ Data Penelitian } & Waktu Pemotongan (X) & Waktu Pemesinan (Y) \\
\hline \multirow[t]{2}{*}{ Uji Normalitas } & & p-value $0,1>\alpha=0,05$ & p-value $1,09>\alpha=0,05$ \\
\hline & Kondisi & Normal & Normal \\
\hline \multicolumn{2}{|l|}{ Uji Homogenitas } & \multicolumn{2}{|c|}{$\chi_{\text {hitung }}^{2}=0,2118<\chi_{\text {tabel }}^{2}=3,841$} \\
\hline & Kondisi & \multicolumn{2}{|c|}{ Homogen } \\
\hline \multicolumn{2}{|c|}{ Uji Regresi Sederhana } & \multicolumn{2}{|c|}{$\hat{\mathrm{Y}}=73,64+2,07 \mathrm{X}$} \\
\hline \multicolumn{2}{|c|}{ Perhitungan Koefisien Korelasi } & \multicolumn{2}{|c|}{$r=0,9796$} \\
\hline & Kondisi & \multicolumn{2}{|c|}{ Sangat Kuat } \\
\hline \multicolumn{2}{|c|}{ Pengujian Hipotesis } & \multicolumn{2}{|c|}{$\mathrm{t}_{\text {hitung }}=25,77>\mathrm{t}_{\text {tabel }}=1,701$} \\
\hline & Kondisi & \multicolumn{2}{|c|}{$\mathrm{H}_{\mathrm{a}}$ diterima dan $\mathrm{H}_{0}$ ditolak } \\
\hline
\end{tabular}

Apabila garis regresi yang terbaik untuk sekumpulan data berbentuk linier, maka derajat hubungannya akan dinyatakan dengan $\mathrm{r}$ dan biasa dinamakan koefisien korelasi. Berdasarkan analisis data, dhasilkan harga koefisien korelasi sebesar 0,98. Setelah didapatkan harga koefisien korelasi, maka harga koefisien korelasi tersebut diinterpretasikan terhadap tabel kriteria pedoman koefisien korelasi untuk mengetahui tingkat hubungan yang terjadi. Hasil penginterpretasian diketahui bahwa harga koefisien korelasi sebesar 0,98 terletak pada kategori tingkat hubungan sangat kuat. Sehingga dapat dikatakan hubungan yang sangat kuat antara waktu pemotongan terhadap waktu pemesinan pada uji kompetensi praktek kejuruan bidang pemesinan bubut.

Pengujian hipotesis dihasilkan harga $t_{\text {hitung }}$ sebesar 25,77 dan $t_{\text {tabel }}$ sebesar 1,701 dengan $\mathrm{dk}=28$ dan taraf kesalahan atau taraf signifikansi $(\alpha)$ sebesar 0,05 dengan taraf kepercayaan $95 \%$. Harga $t_{\text {hitung }}$ lebih besar daripada harga $t_{t a b e l}$, dengan kata lain bahwa harga $t_{\text {hitung }}$ berada di daerah penolakan Ho, maka Ho ditolak dan Ha diterima. Sehingga dapat dijelaskan, bahwa adanya hubungan yang sangat kuat antara waktu pemotongan dengan waktu pemesinan pada uji kompetensi praktek kejuruan bidang pemesinan bubut.

\section{PEMBAHASAN}

Setelah melakukan pengolahan data, ditemukan rata-rata waktu pemotongan dan waktu pemesinan. Untuk gambaran waktu pemotongan menghasilkan rata-rata sebesar 80,2 menit, sedangkan untuk waktu pemesinan sendiri menghasilkan rata-rata sebesar 
240,1 menit. Mengacu pada nilai rata-rata tersebut penulis berpendapat bahwa dari data nilai rata-rata tersebut tampak perbedaan yang sangat tinggi antara waktu pemotongan dan waktu pemesinan. Hal tersebut sesuai pada saat pelaksanaan uji kompetensi praktik kejuruan berlangsung. Menentukan waktu pemotongan, bisa dihitung dengan menentukan panjang pemesinan (mm) dibagi dengan kecepatan makan (mm/putaran) (Rochim, 2007). Dalam hal ini, diestimasikan waktu pemotongan pada masing-masing proses pekerjaan membubut dan waktu pemesinan dalam memproses benda kerja pada pelaksanaan uji kompetensi praktik kejuruan. Dihasilkan waktu pemotongan selama 51 menit dan waktu pemesinan selama 180 menit. Hasil dari estimasi tersebut berbeda dengan waktu pemotongan dan waktu pemesinan hasil observasi.. Hal tersebut disebabkan oleh beberapa faktor, antara lain jenis teknologi pembubutan yang diterapkan di sekolah tidak secanggih dengan penerapan teknologi yang digunakan di industri. Khususnya pada penggunaan pahat bubut yang digunakan. Penggunaan pahat bubut di industri biasanya di dominasi dengan penggunaan pahat karbida sedangkan untuk kalangan pendidikan. Dalam hal ini, sekolah didominasi dengan penggunaan pahat baja berkecepatan tinggi atau HSS (high speed steel). Hal lain yang menyebabkan lamanya waktu pengerjaan di tempat. Hasil observasi yaitu adanya perbedaan pengalaman yang dimiliki oleh masing-masing operator. Operator mesin bubut di industri relatif memiliki pengalaman yang lebih dalam menangani pekerjaan-pekerjaan pembubutan. Sehingga operator mesin bubut di industri lebih terampil dalam memanfaatkan ketersediaan waktu yang diberikan (Wena, 2011).

Hasil tersebut digunakan untuk merancang format penilaian yang merupakan rekayasa dari format penilaian yang dibuat oleh BSNP. Dalam rancangan penilaian tersebut, penilaian dibagi ke dalam empat kategori. Kategori A adalah lebih kecil sama dengan waktu rata-rata dikurangi satu standar deviasi. Kategori B lebih besar dari waktu rata-rata dikurangi satu standar deviasi dan lebih kecil sama dengan waktu rata-rata. Kategori $\mathrm{C}$ ditentukan dengan kriteria lebih besar dari waktu rata-rata dan lebih kecil sama dengan waktu rata-rata ditambah satu standar deviasi. Jika waktu penyelesaian lebih besar dari waktu rata-rata ditambah satu standar deviasi, maka siswa tersebut termasuk kategori E. Dalam hal ini, mengaplikasikan rancangan kriteria penilaian waktu pemesinan di atas terhadap hasil waktu pengerjaan yang telah dilakukan oleh peserta uji kompetensi praktik kejuruan (Gambar 1). 


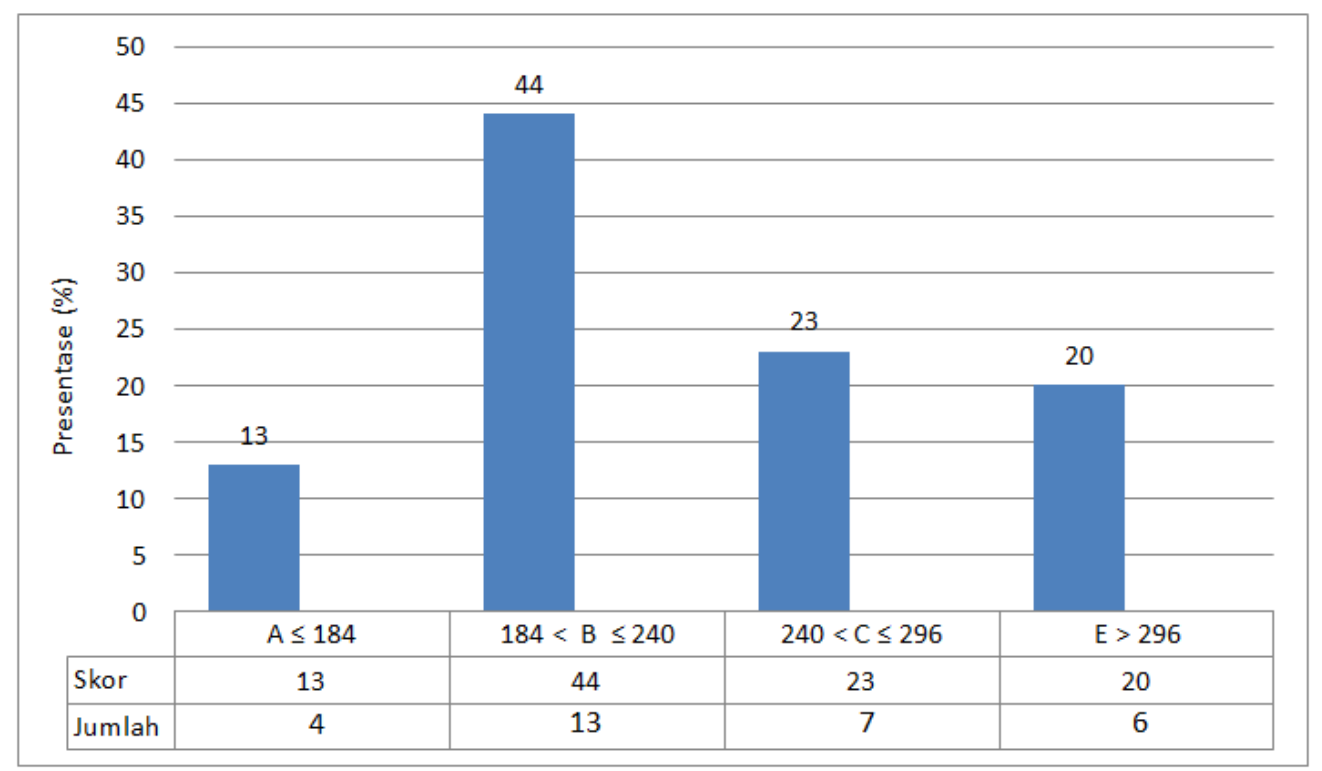

Gambar 1. Grafik Penilaian Waktu Pemesinan

Gambar 1 merupakan grafik yang menggambarkan nilai siswa dengan menggunakan perhitungan rata-rata dan standar deviasi pada tiap rentang waktu pemesinan. Sehingga menghasilkan, empat orang siswa yang mendapatkan nilai A, 13 orang siswa mendapatkan nilai $\mathrm{B}$, tujuh orang siswa mendapatkan nilai $\mathrm{C}$, dan terdapat enam orang siswa mendapatkan nilai E. Selanjutnya dibuat format penilaian yang baru dan mengembangkan dari format penilaian yang dikeluarkan oleh BSNP.

Tabel 3. Format penilaian waktu pemesinan bubut

\begin{tabular}{clc}
\hline \multicolumn{1}{c}{ Komponen } & \multicolumn{1}{c}{ Kriteria } & Skor \\
\hline \multirow{3}{*}{$\begin{array}{l}\text { Waktu } \\
\text { Penyelesaian }\end{array}$} & $\begin{array}{l}\text { Siswa mampu menyelesaikan pekerjaan lebih cepat } \\
\text { dari 184 menit }\end{array}$ & 4 \\
\cline { 2 - 3 } & $\begin{array}{l}\text { Siswa mampu menyelesaikan pekerjaan 184 menit } \\
\text { sampai 240 menit }\end{array}$ & 3 \\
\cline { 2 - 3 } & $\begin{array}{l}\text { Siswa mampu menyelesaikan pekerjaan 240 menit } \\
\text { sampai 296 menit }\end{array}$ & 2 \\
\cline { 2 - 3 } & Pekerjaan diselesaikan melebihi 296 menit & 0 \\
\hline
\end{tabular}

Pada tabel 3, tampak jelas kriteria waktu penyelesaian yang seharusnya dipatuhi atau dijalankan oleh peserta uji kompetensi praktik kejuruan. Dibandingkan dengan format penilaian yang dikeluarkan oleh BSNP, format penilaian diatas dianggap lebih jelas. Pada format penilaian tersebut memuat angka pasti atau kepastian waktu yang disajikan kepada peserta uji kompetensi. Sehingga peserta uji kompetensi mengetahui patokan waktu yang jelas dalam menyelesaikan pekerjaannya demi mendapatkan skor yang optimal. Selain daripada itu, bagi pihak penguji meliputi guru pengajar dan assesor, format penilaian 
tersebut dapat memudahkan mereka dalam memberikan skor yang jelas sesuai dengan waktu penyelesaian yang diselesaikan oleh peserta uji kompetensi praktik kejuruan. Format penilaian diatas memaparkan kriteria waktu yang terukur dalam satuan waktu yang jelas (Muslich, 2011). Sehingga dapat memperkecil kesalahpahaman persepsi waktu penyelesaian. Adapun dengan adanya format penilaian tersebut diatas, dapat memberikan informasi yang jelas kepada stakeholder dan industri terkait atas kompetensi yang dimiliki oleh peserta uji kompetensi praktik kejuruan.

\section{KESIMPULAN}

Rata-rata waktu pemotongan pada pelaksanaan uji kompetensi praktik kejuruan bidang pemesinan bubut yaitu 80 menit, sedangkan rata-rata waktu pemesinan pada pelaksanaan uji kompetensi praktik kejuruan bidang keahlian pemesinan bubut yaitu 240 menit. Ada hubungan antara waktu pemotongan dan waktu pemesinan pada pelaksanaan uji kompetensi praktik kejuruan bidang pemesinan bubut dengan kategori sangat kuat. Dihasilkan format penilaian untuk menilai aspek waktu pemesinan bubut dengan rumus: A $\leq \overline{\mathrm{X}}-S, \overline{\mathrm{X}}-S<B \leq \overline{\mathrm{X}}, \overline{\mathrm{X}}<C \leq \overline{\mathrm{X}}+\mathrm{S}$, dan $E>\overline{\mathrm{X}}+\mathrm{S}$.

\section{DAFTAR PUSTAKA}

Badan Standar Nasional Pendidikan. (2013). Pedoman Penyelenggaraan Uji Kompetensi Keahlian (SMK) Tahun Pelajaran 2013/2014. Jakarta: BSNP.

Direktorat Pembinan SMK. (2013). Pedoman Penyelenggaraan Uji Kompetensi Keahlian (UKK) SMK Tahun Pelajaran 2012/2013. Jakarta: Kemendikbud.

Muslich. (2011). Penilaian Berbasis Kelas dan Kompetensi. Bandung: PT. Refika Aditama.

Rochim, T. (2007). Optimasi Proses Pemesinan Ongkos Operasi. Bandung: Lab. Teknik Produksi Jurusan Teknik Mesin FTI-ITB.

Wena. (2011). Strategi Pembelajaran Inovatif Kontamporer Suatu Pendekatan Tinjauan Konseptual Operasional. Jakarta: Bumi Aksara. 